Article

\title{
Compound Inundation Impacts of Coastal Climate Change: Sea-Level Rise, Groundwater Rise, and Coastal Precipitation
}

\author{
Reyhaneh Rahimi ${ }^{1, *}$, Hassan Tavakol-Davani ${ }^{1}{ }^{10}$, Cheyenne Graves ${ }^{1}$, Atalie Gomez ${ }^{1}$ and \\ Mohammadebrahim Fazel Valipour ${ }^{2}$ \\ 1 Urban Water Group, San Diego State University, San Diego, CA 92182, USA; htavakol@sdsu.edu (H.T.-D.); \\ cgraves@sdsu.edu (C.G.); aegomez@sdsu.edu (A.G.) \\ 2 Department of Geology, Islamic Azad University, Mashhad 9187147578, Iran; dr.ef.valipour@gmail.com \\ * Correspondence: rrahiminahouji2237@sdsu.edu
}

Received: 12 August 2020; Accepted: 25 September 2020; Published: 6 October 2020

\begin{abstract}
The importance of considering the compound effects of multiple hazards has increased in recent years due to their catastrophic impacts on human lives and property. Compound effects correspond to events with multiple concurrent or consecutive drivers, e.g., heavy storms, coastal flooding, high tides, and sea level rise (SLR). There is a recent evidence on inundation caused by SLR-driven groundwater rise, and there is a distinct knowledge gap in understanding the compound inundation effects of this phenomenon considering the important hydrologic and hydraulic considerations under compound events. To fill this knowledge gap, we developed a novel analytical framework to understand the movements of the surface flow under typical precipitation events considering their interaction with uprising groundwater and SLR in a coastal watershed located in Oakland Flatlands, CA, USA, home to several disadvantaged communities. This modelling approach simulates the dynamics of compound flooding in two dimensions of the earth surface in a fine resolution, which is critical for devising proper flood management strategies. The reason to focus on disadvantaged coastal communities is that such communities typically encounter disproportionate environmental injustices due to the lack of sufficient drainage capacity in their infrastructure. Our results show that by considering the compound effect of SLR, groundwater inundation and precipitation flooding, the drainage capacity of infrastructure will be substantially exceeded, such that over 700 acres of the built infrastructure could be flooded. This is a considerable increase compared to scenarios that do not consider compound effect, or scenarios that consider inappropriate combinations of driving factors. In sum, our results highlight the significance of considering compound effects in the coastal inundation analyses, with a particular emphasis on the role of groundwater rise.
\end{abstract}

Keywords: sea-level rise; groundwater rise; compound impacts; disadvantaged communities; 2-dimensional modeling

\section{Introduction}

Built infrastructure of coastal regions have been recently found vulnerable to marine inundation as a result of sea-level rise (SLR), particularly in disadvantaged communities. For instance, the sea-level changes that have already occurred in the City of Imperial Beach, California-which is identified as a Disadvantaged Community according to the California Department of Water Resources (DWR) with the majority of its population as Hispanic or Latino according to the 2019 census estimates-have made 5 major pump stations, many of the key stormwater outlets, and other water infrastructure elements, vulnerable to marine inundation [1]. Even $0.5 \mathrm{~m}$ of additional SLR will make miles of pipes, additional 
pump stations, stormwater outlets and system elements vulnerable to inundation in Imperial Beach [1]. Figure 1 illustrates all California communities that are expected to face SLR inundation challenges in this century [2]. The global mean sea level may rise $0.18-0.48 \mathrm{~m}$ by mid-century, and $0.5-1.4 \mathrm{~m}$ by the end of the century $[3,4]$. The recent SLR has been primarily attributed to greenhouse gas (GHG) emissions, which have accelerated the melting of polar ice caps and thermal expansion of sea water [3-6]. In California, records indicate an observed SLR rate of 17-20 cm per century over the past few decades, which is analogous to the global rise [4]. However, the rate of global SLR has accelerated in recent years, and projections suggest the potential for substantially greater SLR over this century and next [4,6,7]. Hauer, Evans [8] considered population growth in their assessment of the effect of SLR on communities in United States, where they found that a 2100 SLR of $0.9 \mathrm{~m}$ places a land area projected to house 4.2 million people at risk of inundation, while $1.8 \mathrm{~m}$ of rise could affect $13.1 \mathrm{million}$ people-approximately two times larger than indicated by current populations.

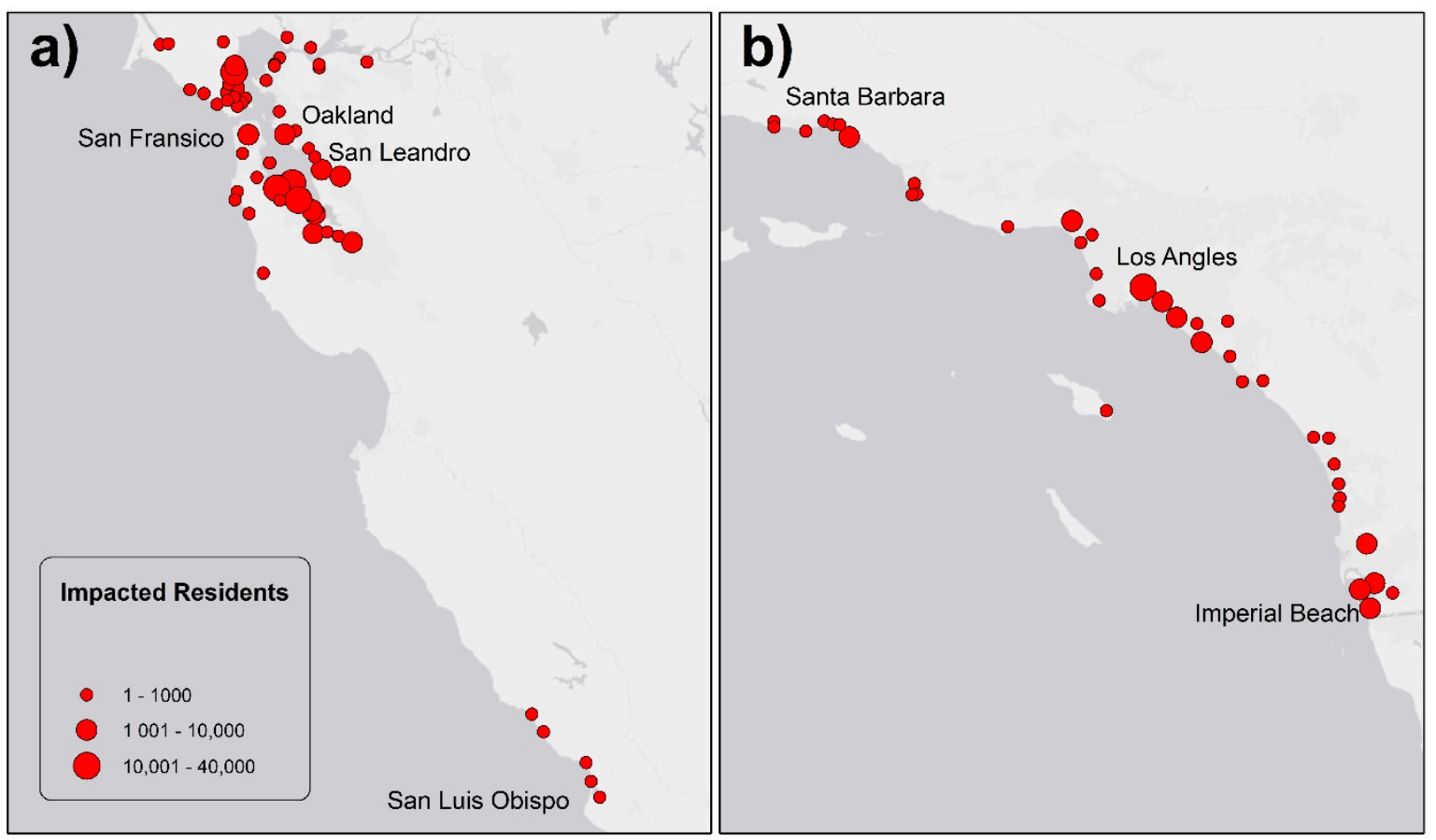

Figure 1. Number of residents in hazard zones caused by $1 \mathrm{~m}$ of SLR (expected to occur in this century) in (a) northern California and (b) southern California. We have achieved data from USGS Hazard Exposure Reporting and Analytics (HERA) that is publicly available [2], and mapped using ArcGIS.

The impacts of SLR on communities and the environment along the California coast are of substantial concern because the majority of the State's population lives in coastal counties (approximately 87\% of the population as of 2014) [9-11]. The California coastline, with a length of over $1800 \mathrm{~km}$ consists of wetlands, estuaries, and coastal resources, and is known as a major asset in the State $[9,12]$. The unprecedented SLR in modern human history may cause catastrophic impacts on this asset [4]. Marine inundation as a result of SLR will shift the coastline landward, erode beaches, accelerate cliff failure, degrade sensitive coastal habitats, and damage coastal infrastructure and humans [2,12-15]. SLR can also contribute to the degradation of coastal aquifers that have already been under pressure in California over the last century due to excessive water extraction and persistent, severe drought [16-19]. Saltwater intrusion into fresh water aquifers in California's coastal regions has been attributed predominantly to ground water overdraft, especially in southern California $[16,17,20,21]$. However, recent studies demonstrate that SLR could also contribute to saltwater intrusion in coastal regions by raising the interface between intruding saltwater and overlying fresh 
water $[14,22]$. Therefore, SLR is expected to impact shallow coastal aquifers resulting in groundwater shoaling and emergence, which is considered another potential source of inundation [14,23,24].

Habel, Fletcher [25] described a modeling approach that simulates narrowing of the unsaturated space and groundwater inundation generated by SLR-induced lifting of coastal groundwater. The methodology combines terrain modeling, groundwater monitoring, estimation of tidal influence, and numerical groundwater-flow modeling to simulate future flood scenarios considering user-specified tide stages and magnitudes of SLR. They applied their method to the heavily urbanized and low-lying areas in Honolulu, Hawaii, USA. Results indicate that SLR of nearly $1 \mathrm{~m}$ generates groundwater inundation across $23 \%$ of the $13 \mathrm{~km}^{2}$ study area, threatening $\$ 5$ billion of real estate and $48 \mathrm{~km}$ of roadway. Befus, Barnard [26] assessed the increasing threat of coastal groundwater hazards from SLR in California. They modeled a range of SLR scenarios to assess the responses of water tables across the diverse topography and climates of the California coast. This research presented that with $1 \mathrm{~m}$ of SLR, flooded areas are predicted to expand 50-130 m inland, and low-lying coastal communities around San Francisco Bay are at a high risk. They illustrated that topography is a controlling factor; long-term rising water tables will intercept low-elevation drainage features, allowing for groundwater discharge that damps the extent of shoaling in 70\% of California's coastal water tables. Davtalab, Mirchi [27] also assessed the effect of sea level rise on groundwater inundation and its consequences on the capacity of retention ponds near Tampa Bay, Florida, USA. They found out that groundwater level rise can significantly reduce the soil storage capacity and cause infiltration at retention ponds, which reduces the ponds' capacity in capturing upcoming storms. Partial groundwater inundation can affect retention ponds' ability to reduce peak flow rates and keep the post-development outflow lower than or equal to pre-development conditions. Apart from causing SLR, climate change can shift the pattern and frequency of precipitation, causing unprecedented surface flooding and inundation [28-30]. In coastal regions, if rainfall over inland areas coincides with higher sea levels (e.g., high tide), impacts of flooding could be exacerbated due to the diminished ability of terrestrial drainage. In sum, emerging inundation sources in coastal regions under a changing climate are (Figure 2): (i) surface flooding as a result of precipitation, (ii) SLR-driven marine inundation, and (iii) SLR-driven groundwater rise.

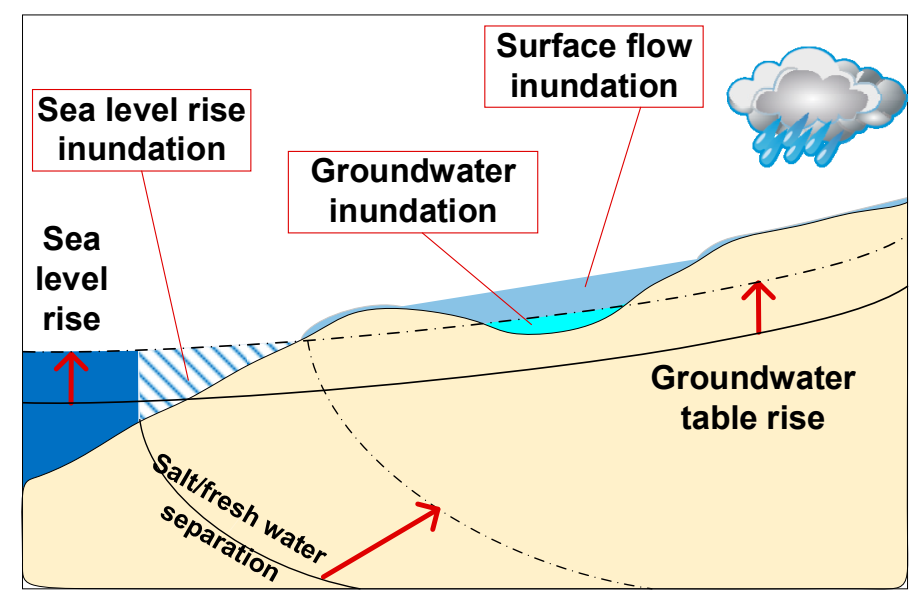

Figure 2. Schematic of emerging sources of inundations in coastal areas under a changing climate.

Therefore, while a natural hazard is conventionally thought of as an infrequent (extreme) event with a short timescale, understanding the compound impacts of above-mentioned stressors occurring on longer timescales or with higher frequency is necessary for devising appropriate adaptation strategies to protect humans, infrastructure, and habitats against impacts of coastal climate change. Such impacts are undoubtedly understudied and have distinct knowledge gaps in identifying appropriate timescales in which these stressors are likely to impact the communities and the operation of infrastructure. Moftakhari, Salvadori [31] proposed a bivariate flood hazard assessment approach that accounts for 
compound flooding from river flow and coastal water level. They showed that a univariate approach may not appropriately characterize the flood hazard if there are compounding effects. Co-occurrence is of paramount importance as it may result in flood hazards with potential impacts larger than each extreme in isolation. Muñoz, Moftakhari [32] used a bivariate statistical analysis linked to hydrodynamic modeling, to quantify compounding effects of flood drivers and generate flood hazard maps near Savannah, Georgia, USA. Using statistical measures, they analyzed compounding effects of terrestrial/coastal flood drivers and wetland elevation correction on maximum floodwater height, and velocity for 50-year return period scenarios. Strauss, Ziemlinski [33] employed high-resolution edition of the National Elevation Dataset, and a tidal model covering the contiguous US, together with data from the 2010 Census, to quantify low-lying coastal land, housing and population relative to local mean high tide levels, which range from 0 to $3 \mathrm{~m}$ in elevation (North American Vertical Datum, a.k.a. NAVD of 1988). They used tidally adjusted approach, and estimated the contiguous US population living on land within $1 \mathrm{~m}$ of high tide to be 3.7 million. In 544 municipalities and 38 counties, they found that over $10 \%$ of the population lives below this line. Sukop, Rogers [34] modeled high temporal resolution of the impact of SLR, tides, and precipitation on water table flooding in the Arch Creek basin, Florida. Their study showed that rain-induced short-term groundwater table rise can be viewed as an important driver factor of flooding events under current conditions.

Numerical models are critically important tools for understanding flooding extent, hazard assessment and flood management planning. Available hydrologic and hydraulic models $(\mathrm{H} \& \mathrm{H})$ of coastal watersheds can solve the continuity and flow motion equations in either 1 dimension along the stream line (1D), 2 dimensions along the land surface (2D), or in 3 dimensions (3D) [35]. Although 1D modeling approaches could be efficient and useful in some contexts, mainly for manmade channels, they face several limitations for overflow analysis [36]. When water begins to overflow, it propagates in 2 dimensions across the Earth's surface, and there is a possibility that the flow return back to the main channel further downstream, which cannot be modeled in 1D platforms. Quirogaa, Kurea [35] have successfully applied the new HEC-RAS version 5 for flood hazardous assessment of the Mamore River flood and showed the 2D capability of the HEC-RAS model to generate flood depth, flow velocity and flood duration. Recent literature shows that 2D numerical models have been successfully applied for flood modeling [37-39]. Rangari et al. (2019), also used HEC-RAS 2D to assess the inundation risk in urban flood for different extreme rainfall scenarios [40].

The focus of the present study is to recognize the SLR-driven groundwater rise and assess its compound effect with the surface flooding caused by precipitation in the San Leandro watershed located in the Oakland Flatland which contains several designated "disadvantage community" blocks. A 2D model is developed for the study area using HEC RAS 5.0.7 to generate flood inundation maps. The paper is organized in four sections. The sections are as follows: methodology, results, conclusion, and discussion.

\section{Methods}

\subsection{Study Area}

The study area is San Leandro watershed (Figure 3) located in Oakland Flatlands, which is home to several disadvantaged community tracts according to DWR. The Flatlands are low-lying areas predominantly comprised of dredged sediment and construction debris adjacent to San Francisco Bay, Alameda Estuary, and San Leandro Bay [41]. Census data discloses a disproportionate concentration of poverty in the Flatlands, affecting a population that is majority African American, and Hispanic or Latino. Most of Oakland's White population lives in the more prosperous foothills and hills neighborhoods [41]. There is literature available on the high probability of groundwater rise due to SLR in San Leandro downstream [23]. 


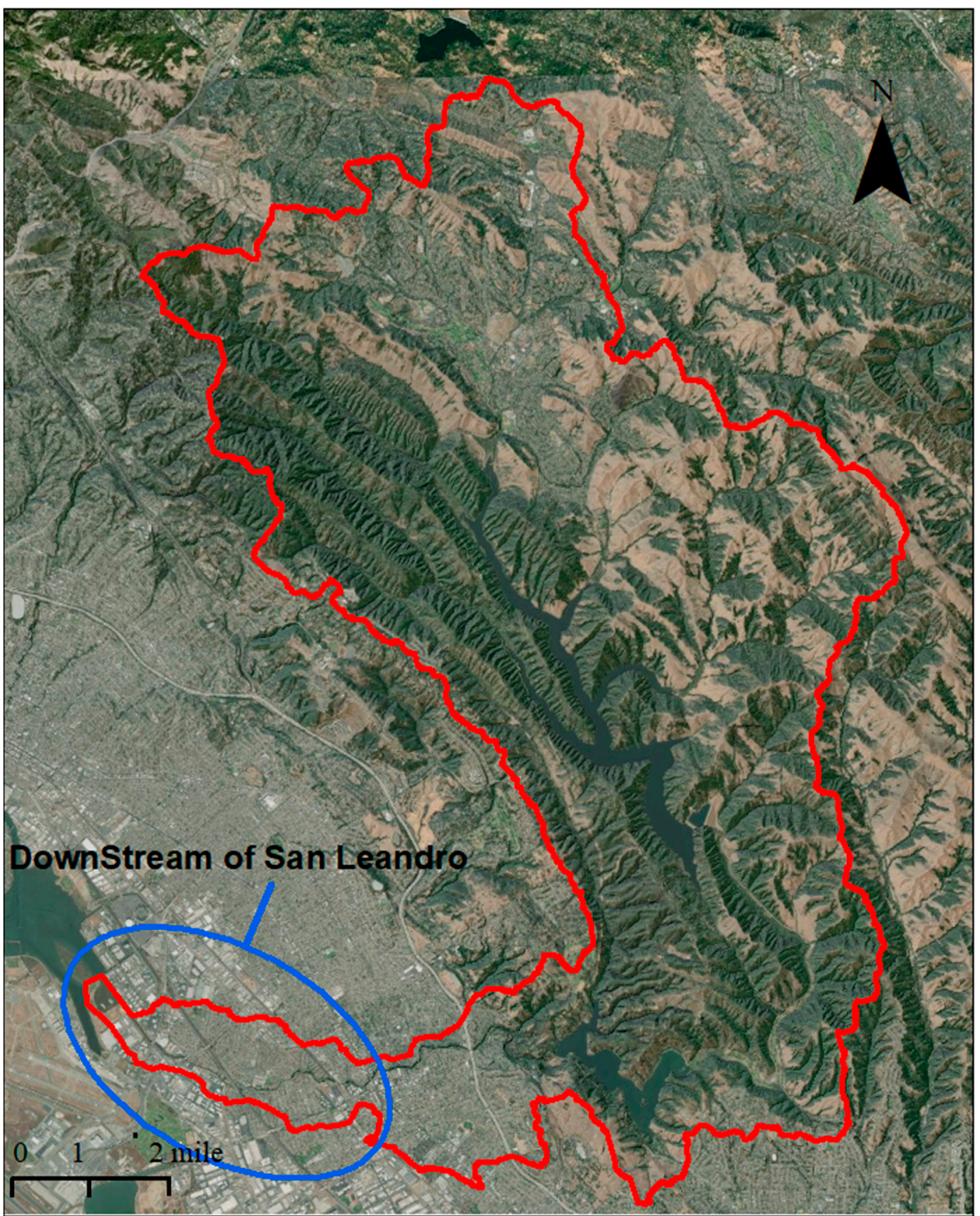

Figure 3. San Leandro watershed. The blue elliptic represents the region that modelled in this study.

The San Leandro Creek watershed (Figure 3) covers 49.4 square miles in the counties of Alameda and Contra Costa. The Alameda County Flood Control and Water Conservation District reports that the creek itself is 22 miles long and is in a natural uncovered state [42]. The City of San Leandro is largely composed of sandstone, shale, serpentine outcrops (found underneath Lake Chabot), rhyolite, and conglomerate from the Cretaceous period [43]. The Oakland Flatlands generally sit on a base of Franciscan Formation, a sedimentary rock formation composed of sandstone, black shale, red chert, grey limestone, and greenstone, a volcanic rock [44]. San Leandro's rich alluvial soils and temperate climate support a wide variety of plants and animals. Wetlands in the southwest part of San Leandro provide habitat for the salt marsh harvest mouse and other special status species. San Leandro Creek remains one of the few waterways in the urbanized East Bay that retains its natural character along 
most of its course. Oakland and San Leandro, CA, share the Mediterranean climate that characterizes the immediate San Francisco Bay Area [45]. Mild, wet winters and dry, cool summers are typical of the weather of both cities [45]. According to the San Francisco Bay Regional Water Quality Control Board, it is one of the few East Bay Creeks that is entirely above ground. The Water Board also reports that the annual rainfall in the watershed ranges from 18-28 inches per year [46]. A study performed by the San Francisco Estuary Institute for the years 1998-2007 estimated the average rainfall for the San Leandro Creek below Lake Chabot is $21 \mathrm{~mm}$. According to that study, flooding information was as follows: minimum first flood volume was $64,000 \mathrm{~m}^{3}$, max first flood volume was $414,000 \mathrm{~m}^{3}$, and average first flood volume was $186,000 \mathrm{~m}^{3}$. The minimum largest flood volume was $230,000 \mathrm{~m}^{3}$, maximum largest flood volume was $907,000 \mathrm{~m}^{3}$, and the average largest flood volume was $490,000 \mathrm{~m}^{3}$. According to the USGS Stream Stats, the two year peak flow in the San Leandro watershed is around $1460 \mathrm{cfs}$.

Although energetic waves caused by coastal storms can be disastrous events in many coastal communities, in areas located around bays, e.g., San Francisco Bay, their impacts are diminished, and thus they are not included in the compound effect analysis presented herein. This claim has been proven by the USGS HERA inundation analyses, which represent the trivial impact of even a 100-year coastal storm on the inundation in San Leandro Bay [2].

In this study, a 3 m DEM (digital elevation model) is used as an input of the HEC-RAS 2D model. The DEM is available on the USDA website and is a part of the National Elevation Dataset (NED) [47]. NED is a seamless mosaic of best-available elevation data. The vertical datum is NAVD88. Other parameters required to develop the model are surface roughness, boundary conditions, and rainfall data. The surface roughness can be input to the model as Manning's roughness coefficient. Manning's roughness coefficient (n) for urban catchments can be evaluated from land use classification and the properties of the soil. In the study area of this paper, we have defined 6 different land uses, as river, roads, open areas, buildings, asphalt/concrete, and marshes, and calibrated the value of Manning's roughness coefficient for each land use. Regarding the boundary condition, a typical precipitation event, i.e., 2-year peak flow (1460 cfs), is used as an upstream boundary condition to show expectable situations, as opposed to extreme events (e.g., 100- or 500-year events). The value of the 2-year peak flow was obtained from the USGS Stream Stats application. The effects of SLR and groundwater rise will occur on longer timescales as compared with acute storms. Therefore, SLR and groundwater rise have been modeled as the model's boundary condition via three different scenarios:

1. In the first scenario, the value of MHHW (mean higher high water) which is $1.94 \mathrm{~m}$ is used as downstream boundary condition [48];

2. In the second scenario $1 \mathrm{~m}$ SLR is added to MHHW value; and

3. In the third scenario groundwater inundation is also considered as a downstream boundary condition.

\subsection{Modelling}

A. Framework and Data Processing: Figure 4 represents the flowchart of the proposed methodology:

The core part of the methodology is constructing a representative 2D flooding model which has three steps as it can be seen in Figure 4. The first step is to processing the input files, including DEM data, roughness layers, and the geometry of the watershed. As mentioned in the previous section, we have used $3 \mathrm{~m} \mathrm{DEM}$, and 6 different roughness value for the defined domain of the downstream watershed. The second step is to develop groundwater inundation depth values which will be used as one of boundary conditions in the third step. For groundwater rise projection, we have obtained and processed data from literature as follows. In shallow, unconfined aquifers along the coast, SLR will increase recharge from seawater, increasing groundwater levels over longer time scales [14,23]. Where unconfined fresh groundwater is in contact with underlying seawater, the fresh groundwater floats on the higher-density seawater, and the average elevation of the water table will be above mean sea-level [49]. Near the coast, both the sea water and saline or overlying fresh groundwater respond to 
forcing, with the magnitude of the response diminishing towards the inland from the coast $[14,50,51]$. SLR will cause the groundwater table to rise in these areas, and in low-lying areas the water table could approach and ultimately rise above the ground surface [14,24]. This study uses the findings of a previous study of Plane, Hill [23] to identify potential groundwater flooding hotspots as sea levels rises in coastal cities. In their study, they used empirical depth-to-water data and a DEM of the San Francisco Bay Area to construct an interpolated surface of estimated minimum depth to water. Then, by subtracting the surface from the DEM, the groundwater inundation map is generated.

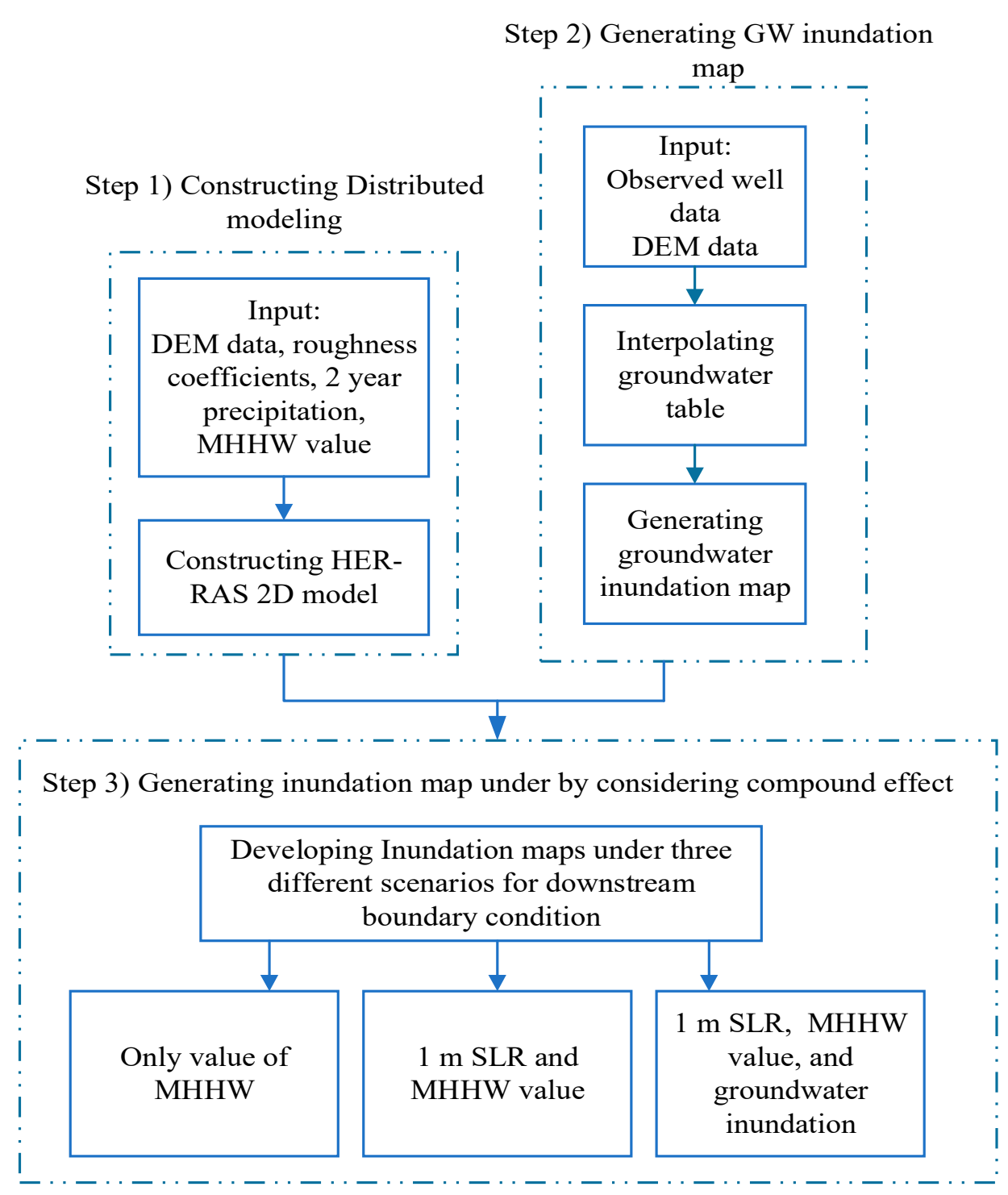

Figure 4. The flowchart of the proposed methodology for developing inundation map of studied compound effects.

Finally, in the third step, inundation maps will be generated as the results of HEC-RAS output. As mentioned before, this study develops maps for three different downstream boundary conditions in order to assess the compound effect of mentioned factors on the inundation of low-lying coastal area. In the next paragraph, the detailed calculation of HEC-RAS model is presented. The outputs of this model are the illustrative inundation map that are represented in the Result section. 


\section{B. Modeling Concepts:}

A distributed model was developed using a 2-dimensional, unsteady modeling of inundation under a 2-year precipitation event. Groundwater inundation and SLR heights were used as the boundary conditions. This modelling approach simulates the dynamics of compound inundation in a fine resolution, which is critical for devising proper flood management strategies. To validate the Stream Stats estimates, the IDF (intensity duration frequency) curves are analyzed, using the frequency of interest (2-year) and duration of interest (24-h, as the basis for flood analysis) to achieve the precipitation intensity. Then, precipitation intensity is translated to pick discharge rates using Modified Rational Method [52] for the watersheds of interest. Next, to enable unsteady modeling, runoff hydrographs are developed using the soils conservation service (SCS) triangular hydrograph method [53]. The following equations are used to define the shape of the triangular hydrograph.

$$
\begin{gathered}
\mathrm{T}_{\mathrm{L}}=\frac{1^{0.8}\left(\frac{1000}{\mathrm{CN}}-9\right)^{0.7}}{1900 \mathrm{Y}^{0.5}} \\
\mathrm{~T}_{\mathrm{p}}=\frac{\Delta \mathrm{D}}{2}+\mathrm{T}_{\mathrm{L}} \\
\mathrm{Q}_{\mathrm{p}}=\frac{484 \mathrm{~A}}{\mathrm{~T}_{\mathrm{p}}} \\
\mathrm{T}_{\mathrm{b}}=1.67 \mathrm{~T}_{\mathrm{p}}
\end{gathered}
$$

where $T_{L}$ is lag time $(h), l$ is flow length ( $\left.f t\right), C N$ is curve number, $Y$ is average watershed slope $(\%), T_{p}$ is time to peak (h), $\Delta \mathrm{D}$ is duration of rainfall (h), $\mathrm{Q}_{\mathrm{p}}$ is peak discharge (cfs), $\mathrm{A}$ is area $\left(\mathrm{mi}^{2}\right)$, and $\mathrm{T}_{\mathrm{b}}$ is time to base (h). Figure 5 represents the flow hydrograph of the catchment developed by applying SCS triangular hydrograph method. The duration of rainfall, and CN are considered as $24 \mathrm{~h}$ and 0.85 , respectively. Excess rainfall is the rainfall that directly contributes to the surface runoff. It is calculated by subtracting the losses and/or abstractions from the total rainfall.

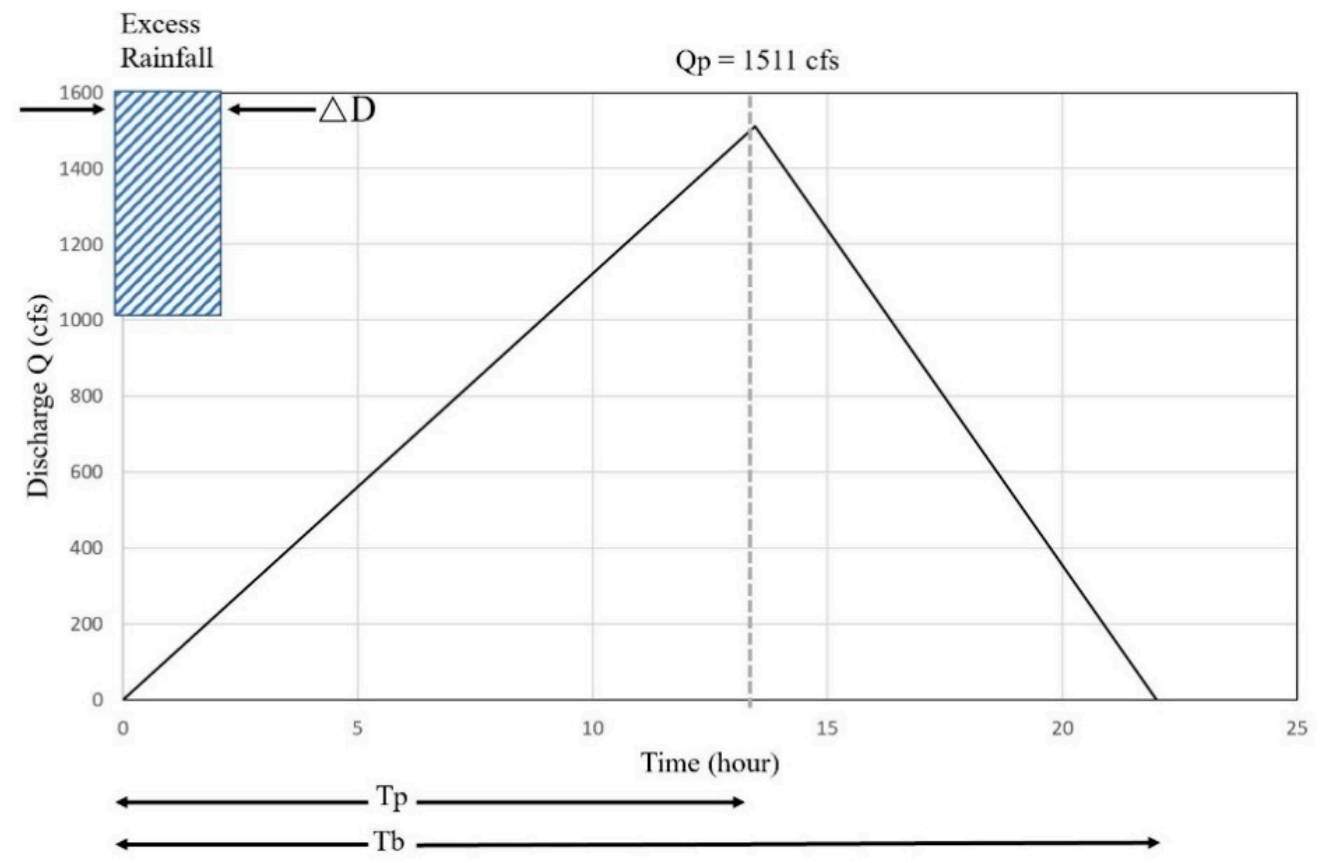

Figure 5. 2-year precipitation hydrograph for San Leandro Watershed using soils conservation service (SCS) triangle method. 
For simulating inundation under SLR, groundwater rise and extreme precipitation conditions, we have used the diffusion wave equation (Equation (5)) and unsteady differential form of the conservation of the mass equation (Equation (6)). The diffusion wave form of the momentum equation disregards the unsteady, advection, turbulence and Coriolis terms [35]:

$$
\begin{gathered}
-\mathrm{g} \nabla \mathrm{H}=\mathrm{c}_{\mathrm{f}} \mathrm{V} \\
\frac{\partial \mathrm{H}}{\partial \mathrm{t}}+\nabla \cdot \mathrm{hV}+\mathrm{q}=0
\end{gathered}
$$

where $g$ is gravitational acceleration, $\nabla(\partial / \partial x, \partial / \partial y)$ is vector of the partial derivative in the $x$ and $y$ directions, $H$ is water surface elevation, $c_{f}$ is bottom friction coefficient, $V(u, v)$ is velocity (where $u$ and $\mathrm{v}$ are respectively the velocity components in the $\mathrm{x}$ and $\mathrm{y}$ directions), $\mathrm{t}$ is time, $\mathrm{h}$ is water depth, and $\mathrm{q}$ is a source or sink term. Using Manning's equation to represent bottom friction, Equation (5) will turn into:

$$
-\mathrm{g} \nabla \mathrm{H}=\left(\frac{\mathrm{n}^{2} \mathrm{~g}|\mathrm{~V}|}{\mathrm{R}^{\frac{4}{3}}}\right) \mathrm{V}
$$

where $\mathrm{n}$ is Manning's roughness coefficient, and $\mathrm{R}$ is hydraulic radius. The velocity can be determined by assuming that flow movement is driven by the balance between the barotropic pressure gradient and bottom friction (8). Lastly, the diffusion wave is substituted into the continuity equation to derive a single equation model, the diffusion wave approximation, which is used to solve for $\mathrm{H}$, the water surface elevation (WSE) (9):

$$
\begin{gathered}
\mathrm{V}=-\left((\mathrm{R}(\mathrm{H}))^{\frac{2}{3}} / \mathrm{n}\right) \frac{(\nabla \mathrm{H})}{|\nabla \mathrm{H}|^{\frac{1}{2}}} \\
\frac{\partial \mathrm{H}}{\partial \mathrm{t}}-\nabla \cdot \frac{(\mathrm{R}(\mathrm{H}))^{5 / 3}}{\mathrm{n}|\nabla \mathrm{H}|^{\frac{1}{2}}} \nabla \mathrm{H}+\mathrm{q}=0
\end{gathered}
$$

For 2D calculations, the study area is discretized, encompassing the rivers and adjacent floodplain areas, in a collection of individual grid cells. Each grid cell contains elevation and roughness data to represent the terrain elevation and friction effects used to solve the diffusion wave equations. At each cell face, hydraulic properties (cross-sectional area, wetted perimeter, and hydraulic radius) are computed. Then WSE-volume relationships are computed for each cell and WSE-hydraulic properties relationships are computed for every cell face. Lastly, the diffuse wave equations were solved with an iterative scheme.

The unsteady flood inundation was simulated using the United States Army Corps of Engineer's HEC-RAS 2D. Although the program can solve for either the 2D full Saint-Venant equations or the $2 \mathrm{D}$ diffusion wave equations, the $2 \mathrm{D}$ diffusion wave equations is preferred for analysis, because it provides around the same stable results as the Saint-Venant method for urban inundation problems, but in a much shorter computation time.

The 2D flow area in HEC RAS specifies the extent of area within which 2D flow calculations are performed. It is marked as a hatched polygon layer for the study area in Figure 6. A computational 2D mesh is established within the defined 2D flow area at a cell spacing of $10 \mathrm{~m}$ which generated 60,582 computational cells. The model delivers sufficient accuracy and stability with Courant numbers as high as 5.0 while using the diffusion wave equations. When running a model for a small urban area, Courant numbers less than 1.0 should be used for more output accuracy. Most importantly, the time step used must be sufficient to produce stable results which can be identified rather quickly. Generally, the time step or computation interval for a model simulation run should be small enough to allow water movement through computational cells [54]. The HEC RAS manual suggests $30 \mathrm{~s}$ or shorter as a reasonable time step for a $60 \mathrm{~m}$ cell spacing, though it may vary as long as reasonable results are produced without sacrificing accuracy. In this study, a time interval of $10 \mathrm{~s}$ is selected to produce the highest accuracy in the output without affecting model stability. 


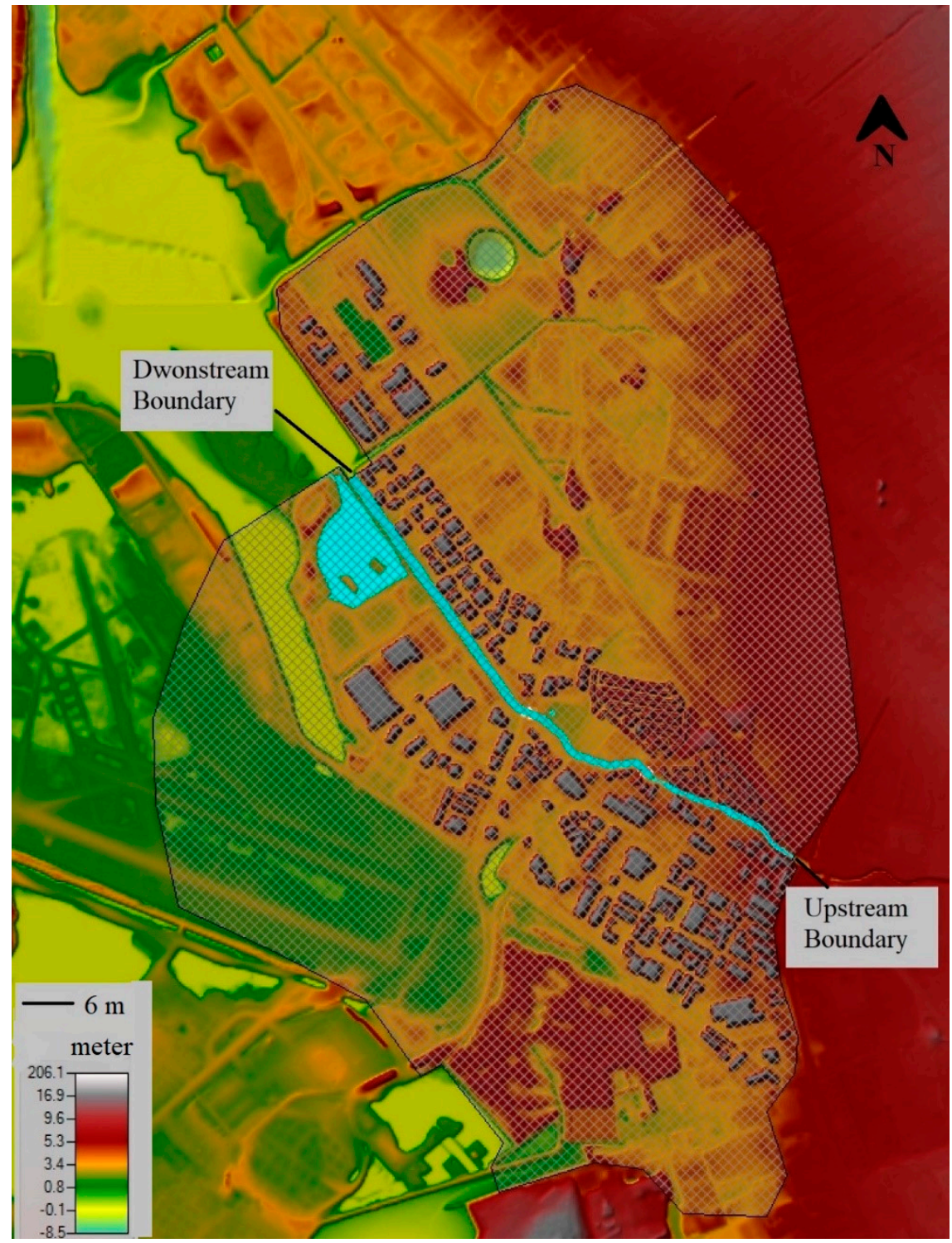

Figure 6. Digital Elevation Model and 2D modeling domain of the study area.

The upstream boundary condition is a unit hydrograph resulted from SCS triangular method explained earlier. For downstream boundary condition, three different scenarios are defined. In the first scenario, the value of MHHW which is $1.94 \mathrm{~m}$ is used as the downstream boundary condition [48]. In the second scenario, $1 \mathrm{~m} \mathrm{SLR}$ is added to MHHW value, and in the third scenario groundwater inundation is also considered as a downstream boundary condition. Inundations caused by groundwater rise are modeled as boundary conditions for the model because it occurs over a much longer period of time. Inundation caused by sea-level rise in a high tide condition is also modeled as the downstream boundary condition for the model. Figure 6 represents the DEM of the watershed modeled in HEC-RAS. It is important to note that we have manipulated the DEM downloaded from USDA to show buildings on earth's surface.

\section{Results}

As discussed earlier, there is a knowledge gap in understanding the compound effects of SLR-driven inundation and precipitation-based flooding using proper timescales. Flow motion in coastal watersheds during rainfall events can cause inundation in additional areas that a static analysis 
of compound effects is unable to identify. It is important to note that there has been an attempt in recent literature to understand the compound effects of flooding sources due to their catastrophic impacts on coastal communities, but those efforts are limited to extreme events, and do not include precipitation-based flooding, as our study did $[32,55,56]$. In previous literature, coastal storms are typically considered with SLR inundation without understanding the interconnections of SLR to groundwater rise [57].

Figure 7 illustrates the results for our study area. As mentioned earlier, San Leandro is home to several "disadvantaged community blocks", according to CA Department of Water Resources (DWR). The figure, which is obtained using the specified methods in the previous section, show the inundated area under Scenario 1 shown in Figure 7a (high tide conditions and 2-year precipitation) and Scenario 2 shown in Figure $7 \mathrm{~b}$ (high tide conditions, $1 \mathrm{~m}$ SLR, and 2-year precipitation) is not significant. The San Leandro creek is not expected to overflow and to affect the buildings under these scenarios. In other words, this projection shows that no part of the built infrastructure is expected to face inundation by such compound impacts. The inundated area in Scenario 2 increases by $9 \%$ compared to Scenario 1 , i.e., when the SLR is taken into account.

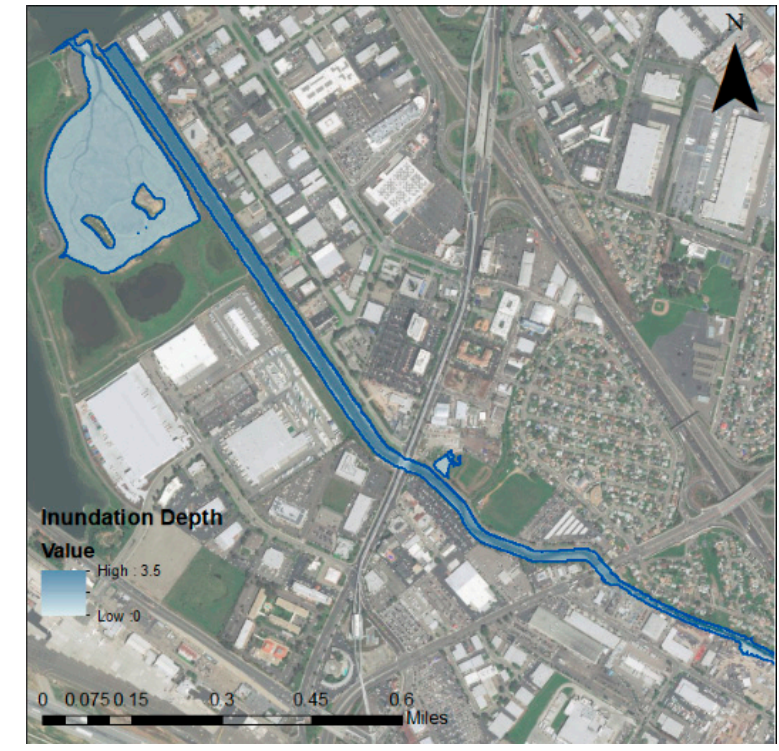

(a)

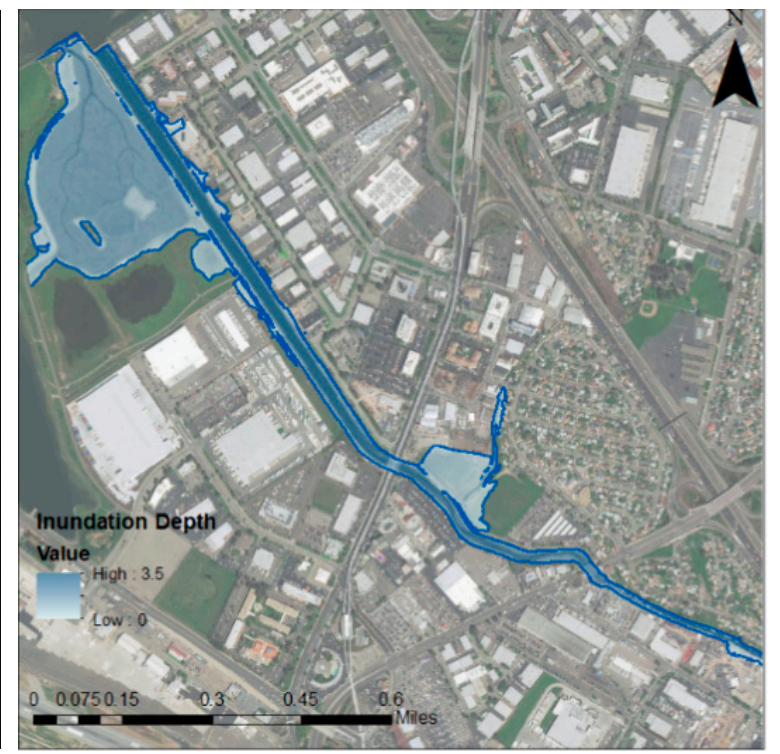

(b)

Figure 7. (a) Blue area shows compound impacts of high tide $(1.94 \mathrm{~m})$ and 2 year precipitation, (b) shows compound impacts of high tide, $1 \mathrm{~m}$ SLR, and a 2-year precipitation.

In contrast, by considering groundwater inundation, a $1 \mathrm{~m}$ SLR, and a 2-year precipitation event "together" as the boundary condition (Scenario 3), a considerable amount of built infrastructure will be inundated (Figure 8). The inundated area in this scenario is 768 acres. As it is evident, elevated tailwater conditions caused by groundwater rise affects the capacity of the channel which causes overflow and will inundate the roads and residential areas, especially those in the downstream portion. Based on these results, we have found that groundwater rise attributed to SLR can both (i) significantly occupy the capacity of drainage infrastructure and (ii) cause elevated tailwater conditions resulting in stream overflow in upstream areas. The extent shown in Figure 8 is identified as a Disadvantaged Community Tract according to DWR. 


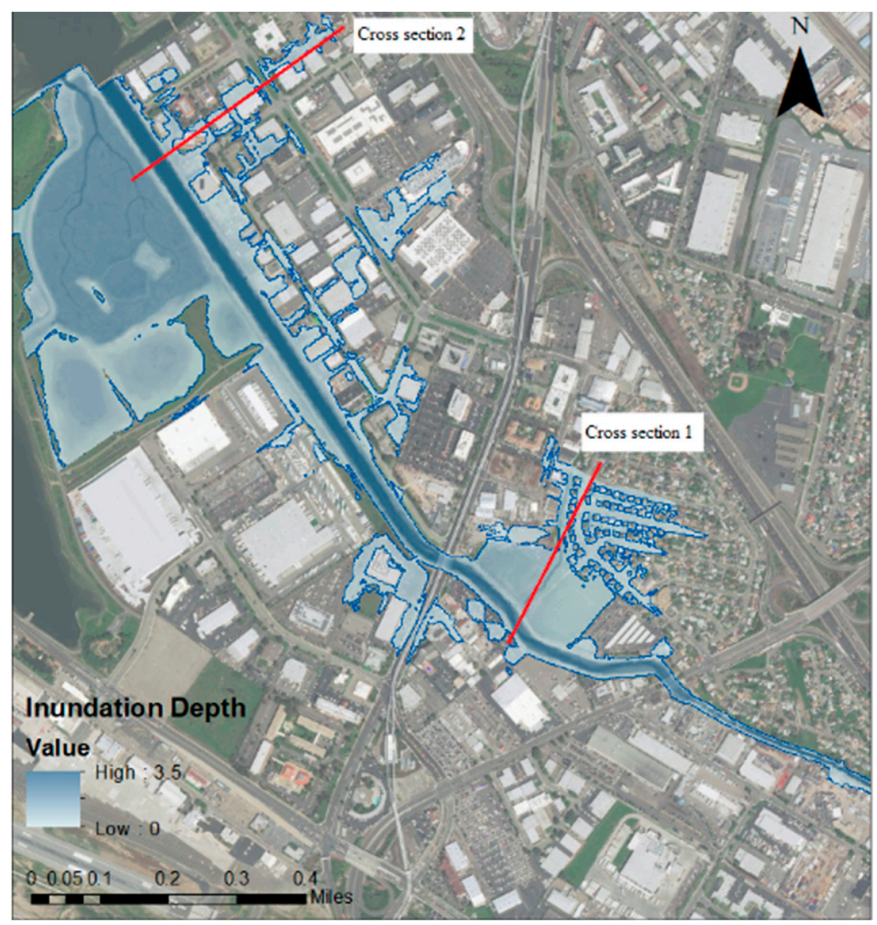

Figure 8. Blue area shows compound impacts of high tide (1.94 m), 1m SLR, groundwater inundation, and 2-year precipitation. Cross Sections 1 and 2 are visualized in Figure 9.

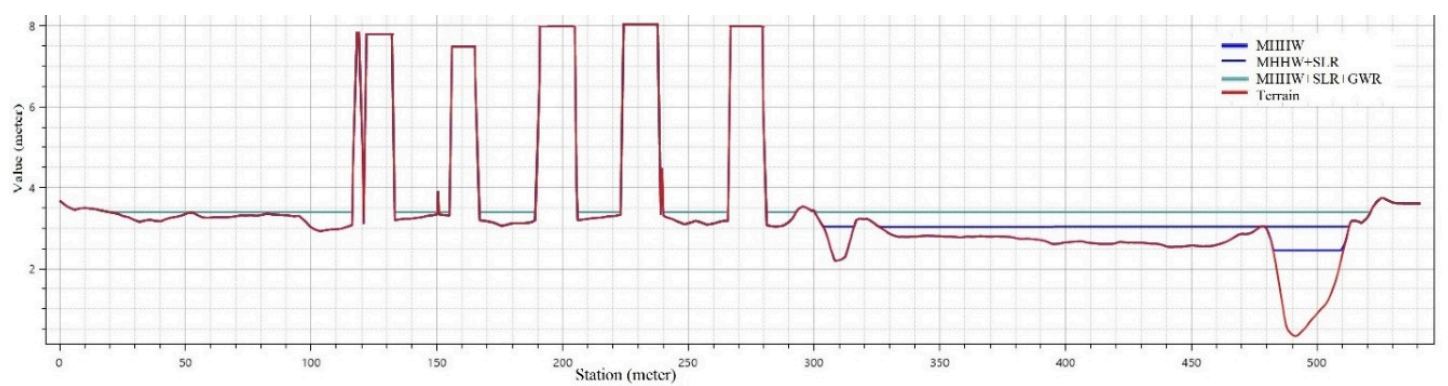

(a)

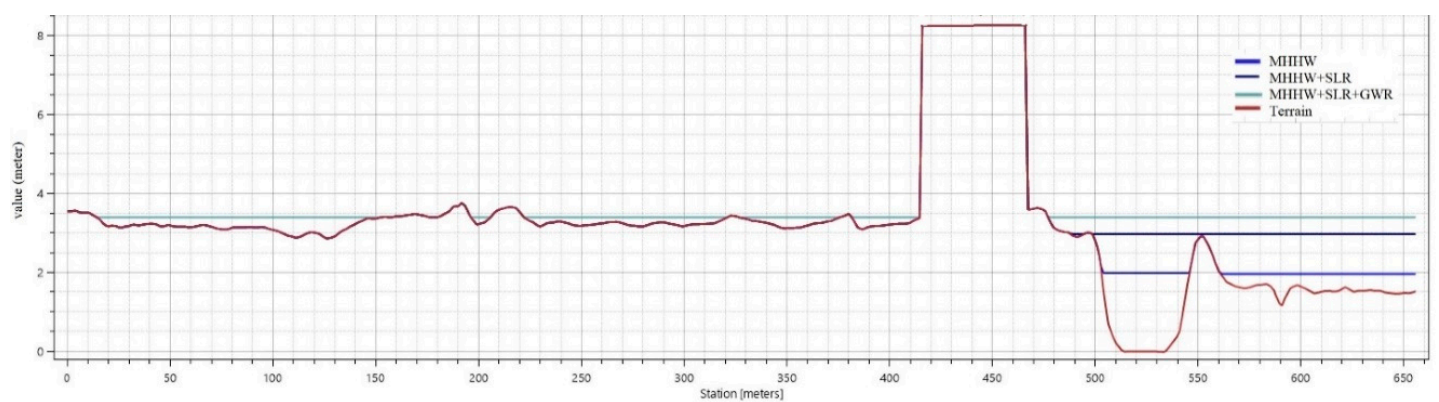

(b)

Figure 9. Water elevation in different scenarios at (a) Cross Section 1, and (b) Cross Section 2.

In order to better represent the water elevation in different scenarios, two cross sections with significant inundation projections are selected to be analyzed. These two cross sections are identified in Figure 8. Figure 9 represents the side view of water elevation in these two cross sections. According to this figure, compound effects can cause a flooding depth of over $0.5 \mathrm{~m}$ in the built infrastructure, which may cause safety issues, especially for the transportation infrastructure. 
Another variable that we analyzed here is the flow velocity. Our findings did not show a significant increase in the velocity of overland flow under the studied scenarios with the risk of impacting the safety of residents.

\section{Discussion}

There are studies available focusing on the compound effect of different driving factors of flooding in coastal areas. Santiago-Collazo, Bilskie [57] presented a comprehensive review of the most recent studies that quantify extreme flooding using variations of a compound inundation model. Their review represents that even most of the recent publications do not consider typical events and they are mostly focus on the "extreme hurricane and coastal surges". Therefore, our method for considering the annual/typical precipitation coupled with other drivers like SLR and groundwater inundation is an innovative approach to assess the expectable inundation, especially in locations where coastal surges do not have paramount role in flooding. $\mathrm{Xu}, \mathrm{Xu}$ [55] assessed the compound effect of precipitation and storm tides as flood drivers in coastal zones in Haikou, China. They figured out that the complex interplay between these two drivers can exacerbate the impacts of flooding. This study investigates the bivariate return period of compounding rainfall and storm tide events based on copula functions and the failure probability is used to assess the variation of bivariate flood risk during the entire project lifetime. Although, this study did not consider the effect of SLR and subsequent impacts, e.g., groundwater rise. Muñoz, Moftakhari [32] assessed the compound effect of high river discharge and extreme coastal water level in Savannah, Georgia, USA. They used a bivariate statistical analysis linked to hydrodynamic modeling to quantify compounding effects of flood drivers. Their results represent that compound flooding analysis in estuaries accounting for not only the likelihood of high river discharge and extreme coastal water levels but also the accuracy of maximum floodwater height and maximum floodwater velocity in coastal flood hazard maps. Furthermore, Liu, Cheng [56] developed a framework for exploring joint effects of conditional factors on compound floods in Texas, USA. These compound drivers consist of combinations of precipitation and surface runoff with the El Nino-Southern Oscillation and rising temperatures as underlying conditions. They mentioned that although the individual variable of precipitation and runoff may not itself be extreme, large exceedances can lead to flooding situations when combined. Sukop, Rogers [34], assessed the impact of SLR, rainfall and tide on groundwater inundation in Southeast Florida, USA. However, they did not work on the compound impact of rainfall, SLR, and groundwater inundation on flooding. By reviewing these recent articles that worked on compound flooding of coastal areas, it is evident that considering the compound effect of SLR, precipitation and groundwater inundation on coastal inundation is understudied. This paper proposed an applicable methodology which can address the flooding issues in coastal areas by providing $2 \mathrm{D}$ inundation projections, and can help decision makers to manage the flooding hazards in a practical manner.

\section{Conclusions}

In recent years, few studies addressed projecting the inundation caused by SLR-driven groundwater rise, and no study paid particular attention to the compound effects of these phenomena. The gap in literature addressing these particular concerns is substantial considering the important hydrologic and hydraulic effects. In the present study, a novel analytical framework was developed to understand the movements of the surface flow under a typical (as opposed to extreme) precipitation event considering the composite interaction with uprising groundwater and sea level rise. In the proposed approach, the dynamics of compound inundation is simulated in a fine resolution, which is critical for devising proper flood management strategies.

In the first step, a contour of the water table that was available in the literature was transformed to the model's boundary conditions. The data required for running HEC-RAS 2D (including DEM, manning roughness coefficients, and boundary conditions) were gathered. In the next step, the HEC-RAS 2D model was developed for three different scenarios, (1) compound effect of 2-year 
precipitation and MHHW; (2) MHHW, 1m SLR, and 2-year precipitation; and (3) MHHW, 1m SLR, groundwater inundation, and 2-year precipitation. The results show that SLR itself is not expected to cause flooding problems in the built infrastructure. However, by incorporating groundwater rise, the inundation projection exceeded 768 acres affecting the urban areas including buildings and transportation infrastructure, especially those located in the downstream of the watershed. These results show the importance of considering SLR-driven groundwater rise when it coincides with precipitation flooding. The importance of combining these has not been addressed in previous studies. For these reasons, this paper aimed to propose an analytical framework to help decision makers understand the importance of these compound effects in coastal communities, specifically in disadvantaged communities.

The model can be applied to any region with minimum input data requirements such as precipitation events, the digital elevation model and catchment properties. The flood risk maps can then be developed by utilizing H\&H models to help develop adaptation strategies. Additionally, the proposed model can be utilized to simulate real-time flood events to map inundated areas and to help local authorities decide on suitable adaptation strategies, such as implementing rainwater harvesting in the upper part of the watershed in order to reduce the amount of precipitation caused flooding.

Author Contributions: R.R. contributed in writing the manuscript, data curation, modeling, and validation. H.T.-D. contributed in development of the methodology, writing and revising the manuscript, software techniques, supervision, and visualization. C.G. contributed in data acquisition. A.G. contributed in. data acquisition and visualization. M.F.V. contributed in the formal analysis and discussions. All authors have read and agreed to the published version of the manuscript.

Funding: This research was funded by Dr. Tavakol-Davani's start-up package at the San Diego State University.

Conflicts of Interest: The authors declare no conflict of interest.

\section{References}

1. Revell, D.L.; King, P.; Snyder, A.; Calil, J.; Gilliam, J.; Slaven, C.; Hart, J.; Boudreau, D.; Nakagawa, J.; Mercer, R.; et al. 2016 City of Imperial Beach Sea Level Rise Assessment; Coastal Conservancy: Imperial Beach, CA, USA, 2016.

2. Jones, J.M.; Wood, N.; Ng, P.; Henry, K.; Jones, J.L.; Peters, J.; Jamieson, M. Community Exposure in California to Coastal Flooding Hazards Enhanced by Climate Change; U.S. Geological Survey: Liston, VA, USA, 2016.

3. Scavia, D.; Field, C.J.; Boesch, F.D.; Buddemeier, W.R.; Burkett, V.; Cayan, R.D.; Fogarty, M.; Harwell, A.M.; Howarth, W.R.; Mason, C.; et al. Climate change impacts on US coastal and marine ecosystems. Estuaries 2002, 25, 149-164. [CrossRef]

4. Cayan, D.R.; Bromirski, P.D.; Hayhoe, K.; Tyree, M.; Dettinger, M.D.; Flick, R.E. Climate change projections of sea level extremes along the California coast. Clim. Chang. 2008, 87, 57-73. [CrossRef]

5. Rahmstorf, S. A semi-empirical approach to projecting future sea-level rise. Science 2007, 315, 368-370. [CrossRef]

6. Mastrandrea, M.D.; Luers, A.L. Climate change in California: Scenarios and approaches for adaptation. Clim. Chang. 2012, 111, 5-16. [CrossRef]

7. Bindoff, L.N.; Willebrand, J.; Artale, V.; Cazenave, A.; Gregory, M.J.; Gulev, S.; Hanawa, K.; le Quere, C.; Levitus, S.; Nojiri, Y. Observations: Oceanic Climate Change and Sea Level; Cambridge University Press: Cambridge, UK, 2007.

8. Hauer, M.E.; Evans, J.M.; Mishra, D.R. Millions projected to be at risk from sea-level rise in the continental United States. Nat. Clim. Chang. 2016, 6, 691-695. [CrossRef]

9. Crossett, K.M.; Culliton, T.J.; Wiley, P.C.; Goodspeed, T.R. Population Trends along the Coastal United States: 1980-2008; US Department of Commerce: Columbia, WA, USA; National Oceanic: Silver Spring, MD, USA; Atmospheric Administration: Silver Spring, MD, USA, 2004; Volume 55.

10. Heberger, M.; Cooley, H.; Herrera, P.; Gleick, P.H.; Moore, E. The Impacts of Sea-Level Rise on the California Coast; California Climate Change Center: San Diego, CA, USA, 2009.

11. Bureau, U.S.C. State and county quickfacts. In Data derived from Population Estimates, American Community Survey, Census of Population and Housing, County Business Patterns, Economic Census, Survey of Business Owners, Building Permits; Consolidated Federal Funds Report; Census of Governments: Burbank, CA, USA, 2013. 
12. Arkema, K.K.; Guannel, G.; Verutes, G.; Wood, S.A.; Guerry, A.; Ruckelshaus, M.; Kareiva, P.; Lacayo, M.; Silver, J.M. Coastal habitats shield people and property from sea-level rise and storms. Nat. Clim. Chang. 2013, 3, 913-918. [CrossRef]

13. Dawson, R.J.; Dickson, M.E.; Nicholls, R.J.; Hall, J.W.; Walkden, M.J.A.; Stansby, P.K.; Mokrech, M.; Richards, J.; Zhou, J.; Milligan, J.; et al. Integrated analysis of risks of coastal flooding and cliff erosion under scenarios of long term change. Clim. Chang. 2009, 95, 249-288. [CrossRef]

14. Rotzoll, K.; Fletcher, C.H. Assessment of groundwater inundation as a consequence of sea-level rise. Nat. Clim. Chang. 2013, 3, 477-481. [CrossRef]

15. Wahl, T.; Jain, S.; Bender, J.; Meyers, S.D.; Luther, M.E. Increasing risk of compound flooding from storm surge and rainfall for major US cities. Nat. Clim. Chang. 2015, 5, 1093-1097. [CrossRef]

16. Hanson, R.T.; Izbicki, J.A.; Reichard, E.G.; Edwards, B.D.; Land, M.; Martin, P. Comparison of groundwater flow in Southern California coastal aquifers. Earth Sci. Urban Ocean. South. Calif. Cont. Borderl. 2009, 454, 345.

17. Nishikawa, T.; Siade, A.J.; Reichard, E.G.; Ponti, D.J.; Canales, A.G.; Johnson, T.A. Stratigraphic controls on seawater intrusion and implications for groundwater management, Dominguez Gap area of Los Angeles, California, USA. Hydrogeol. J. 2009, 17, 1699. [CrossRef]

18. Barlow, P.M.; Reichard, E.G. Saltwater intrusion in coastal regions of North America. Hydrogeol. J. 2010, 18, 247-260. [CrossRef]

19. Kostigen, T.M. Could California's drought last 200 years. Natl. Geogr. Retrieved 2014, 2, 2014.

20. Lynn, E. California Climate Science and Data-for Water Resources Management; California Department of Water Resources: Sacramento, CA, USA, 2015.

21. Zektser, S.; Loáiciga, H.A.; Wolf, J.T. Environmental impacts of groundwater overdraft: Selected case studies in the southwestern United States. Environ. Geol. 2005, 47, 396-404. [CrossRef]

22. Werner, A.D.; Simmons, C.T. Impact of sea-level rise on sea water intrusion in coastal aquifers. Groundwater 2009, 47, 197-204. [CrossRef]

23. Plane, E.; Hill, K.; May, C. A Rapid Assessment Method to Identify Potential Groundwater Flooding Hotspots as Sea Levels Rise in Coastal Cities. Water 2019, 11, 2228. [CrossRef]

24. Bjerklie, D.M.; Mullaney, J.R.; Stone, J.R.; Skinner, B.J.; Ramlow, M.A. Preliminary Investigation of the Effects of Sea-Level Rise on Groundwater Levels in New Haven; US Geological Survey: Reston, VA, USA, 2012.

25. Habel, S.; Fletcher, C.H.; Rotzoll, K.; El-Kadi, A.I. Development of a model to simulate groundwater inundation induced by sea-level rise and high tides in Honolulu. Hawaii Water Res. 2017, 114, 122-134. [CrossRef]

26. Befus, K.M.; Barnard, P.L.; Hoover, D.J.; Finzi Hart, J.A.; Voss, C.I. Increasing threat of coastal groundwater hazards from sea-level rise in California. Nat. Clim. Chang. 2020. [CrossRef]

27. Davtalab, R.; Mirchi, A.; Harris, R.J.; Troilo, M.X.; Madani, K. Sea Level Rise Effect on Groundwater Rise and Stormwater Retention Pond Reliability. Water 2020, 12, 1129. [CrossRef]

28. Sadegh, M.; Moftakhari, H.; Gupta,H.V.; Ragno, E.; Mazdiyasni, O.; Sanders, B.; Matthew, R.; Aghakouchak, A. Multihazard scenarios for analysis of compound extreme events. Geophys. Res. Lett. 2018, 45, 5470-5480. [CrossRef]

29. Sadegh, M.; Moftakhari, H.; Gupta, H.V.; Ragno, E.; Mazdiyasni, O.; Sanders, B.; Matthew, R.; Aghakouchak, A. Extreme precipitation events in the western United States related to tropical forcing. J. Clim. 2000, 13, 793-820.

30. Karamouz, M.; Zahmatkesh, Z.; Goharian, E.; Nazif, S. Combined Impact of Inland and Coastal Floods: Mapping Knowledge Base for Development of Planning Strategies. J. Water Resour. Plan. Manag. 2015, 141, 04014098. [CrossRef]

31. Moftakhari, H.R.; Salvadori, G.; Aghakouchak, A.; Sanders, B.F.; Matthew, R.A. Compounding effects of sea level rise and fluvial flooding. Proc. Natl. Acad. Sci. USA 2017, 114, 9785-9790. [CrossRef] [PubMed]

32. Muñoz, D.F.; Moftakhari, H.; Moradkhani, H. Compound Effects of Flood Drivers and Wetland Elevation Correction on Coastal Flood Hazard Assessment. Water Resour. Res. 2020, 56, e2020WR027544. [CrossRef]

33. Strauss, B.H.; Ziemlinski, R.; Weiss, J.L.; Overpeck, J.T. Tidally adjusted estimates of topographic vulnerability to sea level rise and flooding for the contiguous United States. Environ. Res. Lett. 2012, 7, 014033. [CrossRef]

34. Sukop, M.C.; Rogers, M.; Guannel, G.; Infanti, J.M.; Hagemann, K. High temporal resolution modeling of the impact of rain, tides, and sea level rise on water table flooding in the Arch Creek basin, Miami-Dade County Florida USA. Sci. Total Environ. 2018, 616-617, 1668-1688. [CrossRef] [PubMed] 
35. Quirogaa, V.M.; Kurea, S.; Udoa, K.; Manoa, A. Application of 2D numerical simulation for the analysis of the February 2014 Bolivian Amazonia flood: Application of the new HEC-RAS version 5. Ribagua 2016, 3, 25-33. [CrossRef]

36. Srinivas, K.; Werner, M.; Wright, N. Comparing Forecast Skill of Inundation Models of Differing Complexity: The Case of Upton upon Severn; Taylor \& Francis Group: London, UK, 2009; pp. 85-94.

37. Poretti, I.; de Amicis, M. An approach for flood hazard modelling and mapping in the medium Valtellina. Nat. Hazards Earth Syst. Sci. 2011, 11, 1141-1151. [CrossRef]

38. Quiroga, V.M. Cloud and cluster computing in uncertainty analysis of integrated flood models. J. Hydroinform. 2013, 15, 55-70. [CrossRef]

39. Farooq, M.; Shafique, M.; Khattak, M.S. Flood hazard assessment and mapping of River Swat using HEC-RAS 2D model and high-resolution 12-m TanDEM-X DEM (WorldDEM). Nat. Hazards 2019, 97, 477-492. [CrossRef]

40. Rangari, V.A.; Umamahesh, N.V.; Bhatt, C.M. Assessment of inundation risk in urban floods using HEC RAS 2D. Modeling Earth Syst. Environ. 2019, 5, 1839-1851. [CrossRef]

41. McClintock, N.; Cooper, J.; Khandeshi, S. Assessing the potential contribution of vacant land to urban vegetable production and consumption in Oakland, California. Landsc. Urban Plan. 2013, 111, 46-58. [CrossRef]

42. Creek, W.; Creek, L.; San Leandro, C.; Creek, W.; San Pablo Creek, S.C.; Las Positas, A.; Creek, P.; Creek, B.; San Gregorio, C.; Creek, S.; et al. Water Quality Monitoring and Bioassessment in Nine San Francisco Bay Region Watersheds; San Francisco Bay Regional Water Quality Control Board: Davis, CA, USA, 2007.

43. Mariscal, A. San Leandro Creek Watershed. 2003. Available online: http://online.sfsu.edu/jerry/geo_642/ studentProjects/2003/SanLeandroCreek/San\%20Leandro\%20Creek.Mariscal.pdf (accessed on 20 August 2020).

44. Weber, D.O. Oakland. Hub of the West; Continental Heritage Press: Orange Village, OH, USA, 1981.

45. Gilliam, H. Weather of the San Francisco Bay Region; Univ of California Press: Auckland, CA, USA, 2002.

46. Gilbreath, A.; McKee, L. Memo: Estimates of hydrology in small $(<80 \mathrm{~km} 2)$ urbanized watersheds under dry weather and high flow conditions. Environ. Sci. 2010, 2-51. Available online: https://ssl.sfei.org/sites/ default/files/biblio_files/Estimates_of_hydrology_in_small_urbanized_watersheds_0_1.pdf (accessed on 29 September 2020).

47. USDA. Geospatial Data Getaway. Available online: https://datagateway.nrcs.usda.gov/GDGOrder.aspx (accessed on 10 August 2020).

48. N.O.a.A. Datums for 9414750, Alameda CA. n.d. Available online: https://tidesandcurrents.noaa.gov/ datums.html datum $=$ NAVD88\&units $=1 \&$ epoch $=0 \& \mathrm{id}=9414750 \&$ name=Alameda\&state $=$ CA (accessed on 10 August 2020).

49. Hoover, D.J. Sea-level rise and coastal groundwater inundation and shoaling at select sites in California, USA. J. Hydrol. Reg. Stud. 2017, 11, 234-249. [CrossRef]

50. Cooper, H.H. Sea Water in Coastal Aquifers; Government Printing Office: Washington, DC, USA, 1964.

51. Freeze, R.A.; Cherry, J.A. Physical properties and principles. In Groundwater; Prentice-Hall Inc.: Englewood Cliffs, NJ, USA, 1979; pp. 14-79.

52. Dhakal, N.; Fang, X.; Cleveland, T.; Thompson, D. Revisiting Modified Rational Method. In Proceedings of the World Environmental and Water Resources Congress, Palm Springs, CA, USA, 22-26 May 2011.

53. U.S. Department of Agriculture Hydrographs; USDA Natural Resource Conservation Service (NRCS): Washington, DC, USA, 2004; Volume 16.

54. USACE. HEC-RAS River Analysis System Hydraulic Reference Manual. Version 5.0; Hydrologic Engineering Center Davis: Davis, CA, USA, 2016.

55. Xu, H.; Xu, K.; Lian, J.; Ma, C. Compound effects of rainfall and storm tides on coastal flooding risk. Stoch. Environ. Res. Risk Assess. 2019, 33, 1249-1261. [CrossRef]

56. Liu, Z. A framework for exploring joint effects of conditional factors on compound floods. Water Resour. Res. 2018, 54, 2681-2696. [CrossRef]

57. Santiago-Collazo, F.L.; Bilskie, M.V.; Hagen, S.C. A comprehensive review of compound inundation models in low-gradient coastal watersheds. Environ. Model. Softw. 2019, 119, 166-181. [CrossRef]

(C) 2020 by the authors. Licensee MDPI, Basel, Switzerland. This article is an open access article distributed under the terms and conditions of the Creative Commons Attribution (CC BY) license (http://creativecommons.org/licenses/by/4.0/). 